Uluslararası Mühendislik

\title{
Lavanta (Lavandula angustifolia) Katkısının Yonca Silajlarının Kalitesi Üzerine Etkisi
}

\author{
Effect of Lavender (Lavandula angustifolia) Additive on the Quality of Alfaalfa \\ Silages
}

\author{
Asuman Arslan Duru ${ }^{1}$
}

Uşak Üniversitesi, Ziraat ve Doğa Bilimleri Fakültesi, Zootekni Bölümü, 64200, Uşak, TÜRKIYY..

\section{Öz}

Bu çalışmada, farklı düzeylerde ilave edilen lavanta (Lavandula angustifolia) çiçek +sapının yonca silajlarının kalitesi üzerine etkileri araştırılmıştır. Araştırmada, silaj katkı materyalini oluşturan lavantanın çiçeği ve sapı eşit düzeylerde (\% 50 + \% 50) karıştırılarak kullanılmıştır. Lavanta (çiçek + sap) yonca silajlarına \% 0 (kontrol), 0.5, 1.0, 1.5 ve 2.0 düzeylerinde ilave edilmiştir. Araştırma sonunda, \% 2 lavanta ilavesiyle yonca silajlarının NDF içerikleri artmıştır $(\mathrm{P}<0.05)$. KM, OM, ADF ve HP içerikleri ve duyusal analiz sonuçları bakımından önemli bir farklılık bulunamamıştır $(\mathrm{P}>0.05)$. Kontrol grubunun $\mathrm{pH}$ değeri, \% 2 lavanta katkılı grup dışındaki diğer gruplara nazaran önemli düzeyde düşük olduğu belirlenmiştir (P<0.05). Lavanta katkılı yonca silajlarında asetik asit, bütirik asit, Enterobacteriaceae, Listeria spp, sülfit indirgeyen anaeroblara ve mayaya rastlanmamıştır. Küf içeriği, en düşük \% 0.5 lavanta katkılı gruplarda saptanmıştır. Bu verilere göre, lavantanın (çiçek+sap) yonca silajlarında daha yüksek düzeylerde kullanılması veya sap kısmının ayrılarak çiçek kısmının silaj kalitesine etkisinin araştırılmasına yönelik çalışmalar yapılması gerektiği sonucuna varılmıştır.

\section{Anahtar Kelimeler}

"Yonca, lavanta, silaj, kalite, duyusal, mikrobiyoloji"

\begin{abstract}
In this study, the effects of lavender (Lavandula angustifolia) flowers and stem on the quality of alfaalfa silages added at different levels were investigated. In the research, flower and stem of lavander which constitute the silage additive material were mixed at equal levels $(50 \%+50 \%)$. Lavender (flower + stem) was added to alfaalfa silages at $0 \%$ (control), $0.5,1.0,1.5$ and 2.0 levels. At the end of the study, NDF content of alfaalfa silages increased with the addition of $2 \%$ lavender $(\mathrm{P}<0.05)$. There were no significant difference in the dry matter, organic matter, ADF, crude protein and sensory analysis results $(\mathrm{P}>0.05)$. The $\mathrm{pH}$ value of the control group was found to be significantly lower than the other groups except for the $2 \%$ lavender added group (P $<0.05$ ). Acetic acid, butyric acid, Enterobacteriaceae, Listeria spp., sülfide reducing anaerobes and yeast were not found in the alfaalfa silages added with lavender. Mold content was determined in the lowest $0.5 \%$ lavender-added groups. According to this result, it has been concluded that lavander (flower + stem) should be used at higher levels in alfaalfa silages or studies should be carried out to investigate the effect of the flower part on silage quality by separating the stem part.
\end{abstract}

Key Words

"Alfaalfa, lavander, silage, quality, sensory, microbiology" 


\section{Giriş}

Çok yıllık ve Akdeniz bölgesinde yetişen bir bitki olan lavanta, ballıbabagiller (Lamiaceae) familyasından Lavandula cinsini oluşturan türlerin genel ismidir. Lavantanın başak biçimdeki mor çiçekleri çalıya benzemektedir (Atalay, 2008; Orbay, 2014). Sapı ve çiçeklerinin içerdiği yüksek kaliteli uçucu yağ nedeniyle dünyada kültürü yapılan önemli bir parfüm, kozmetik ve ilaç bitkisidir (Guenther, 1952). Parfüm ve kozmetik sanayiinde kullanılan lavanta uçucu yağı ve lavanta çiçeği ağrı kesici, sakinleştirici, stres kovucu, uykusuzluk giderici, idrar sökücü, kalp güçlendirici, romatizma ağrılarını dindirici, antiseptik, antibiyotik etkisi ve egzama, cilt yanıklığı ve kızarıklığına karşı olumlu etkileri olduğu bilinmektedir (Arabacı\&Bayram, 2005; Kesici Güler vd., 2015). Yine lavantadan elde edilen uçucu yağların rumende metan gazını azaltıcı etkisi olduğu bildirilmiştir (Djabri vd., 2016). Toprak yönünden seçici bir bitki olmayan lavanta kurağa, sıcağa ve soğuğa çok dayanıklı olup kireçęe zengin kuru ve kalkerli topraklarda çok iyi yetişebilmektedir. Vegetatif ve generatif olarak üretilebilen bir bitkidir. Dekara verimi tür, çeşit, iklim ve toprak koşullarına göre 100 ile $500 \mathrm{~kg}$ arasında değişmektedir (Aslancan\&Sarıbaş, 2011).

Hayvancılık işletmesinin toplam giderlerinin \% 65-70'ini yem giderlerinin oluşturduğu bilinmektedir. Hayvan beslemede kullanılacak alternatif yem katkılarının bu giderlerin azalmasına neden olacak dolayısıyla daha düşük maliyetle daha yüksek verim elde edilebilecektir. Birçok faydasının olduğu ve rumende metan gazı oranını azalttığı bilinen ve ayrıca önemli bir yere sahip olabileceği düşünülen lavantanın ruminant hayvan beslemede özelliklerinin daha iyi ortaya konulması ve silajlara katkı olarak değerlendirilme imkânının belirlenmesi önem arz etmektedir. Yapılan literatür araştırmasında lavanta çiçek ve sapı karışımının silolanabilirliğe etkisi konusunda yapılan herhangi bir çalışmaya rastlanmamıştır.

$\mathrm{Bu}$ çalışma ile yoncaya çeşitli düzeylerde ilave edilen lavantanın (çiçek + sap) silaj kalitesinin araştırılması amaçlanmıştır. Bu kapsamda, silolanan lavanta ve yonca karışımının kimyasal, fermentasyon, mikrobiyolojik ve duyusal özellikleri belirlenmiştir.

\section{Materyal ve Metot}

Silo materyali: Araştırmada kullanılan silo ana materyali olan yonca, bölgede faaliyet gösteren bir yetiştiriciden hasat edildiği günden bir gün sonra araziden taze olarak alınmış ve aynı gün silolama yapılmıştır. Silolama dönemi 60 gün devam etmiştir. Silaj örnekleri, 3 paralel olarak 1 lt'lik anaerob cam kavanozlara hazırlanmıştır. Silaj katkı maddesi olarak kullanılan lavanta çiçeği ve sapı eşit oranlarda $(\% 50+\% 50)$ karıştırılmış ve yonca silajlarına fermentasyon artırıcı olarak \% 0 (kontrol), $0.5,1.0,1.5$ ve 2.0 düzeylerinde ilave edilmiştir.

Kimyasal Analizler: Silolamada dönemi sonunda kitleyi temsil edecek şekilde alınan silaj örnekleri sirkülasyonlu etüvde $65^{\circ} \mathrm{C}^{\prime}$ de 48 saat kurutmaya tabi tutulduktan sonra kuru madde değerleri belirlenmiştir (AOAC, 1999). Örnekler kurutulduktan sonra $1 \mathrm{~mm}$ elek çapında ögütülmüş ve AOAC (1999)'da belirtilen şekilde 550 C'de 4 saat kül firınında yakılarak örneklerin ham kül ve Kjeldahl yöntemiyle de ham protein içerikleri saptanmıştır. Asit deterjan fiber (ADF) ve nötr deterjan fiber (NDF) analizleri Van Soest vd. (1991)'nın bildirdiği şekilde Fiber Analyzer (Ankom Technology Corp. Fairport, NY, USA) cihazı kullanılarak yapılmıştır (Ankom, 1998). Silajlar açıldıklarında, silaj örneklerine ait $\mathrm{pH}$ değerleri belirlenmek üzere, $25 \mathrm{~g}$ silaj örneği üzerine $100 \mathrm{ml}$ saf su ilave edilecek ve çalkalayıcı ile karıştırıldıktan sonra elde edilen sıvının pH'sı dijital pH metreyle ölçüm yapılmışır (Polan vd., 1998). Yine silajların açımından hemen sonra $40 \mathrm{~g}$ silaj örneği alınmış ve $360 \mathrm{ml}$ saf su ilave edilerek çalkalanmıştır. Çalkama işlemi sonrasında karışım Whatman no:1 kağıdından süzülmüş ve elde edilen süzükten $100 \mathrm{ml}$ alınarak Kjeldahl distilasyon yöntemiyle $\mathrm{NH}_{3}-\mathrm{N}$ tayini yapılımışır. Aynı filtrattan $2 \mathrm{ml}$ alınarak silajların uçucu yağ asitleri (UYA) ve laktik asit içeriklerini tespit etmek üzere analizlerin gerçekleştirileceği güne kadar $-18^{\circ} \mathrm{C}$ 'de derin dondurucuda muhafaza edilmiş̧ir. Analiz gününde derin dondurucudan alınan örneklerin HPLC cihazında UYA (asetik asit, propiyonik asit ve bütirik asit) ve laktik asit

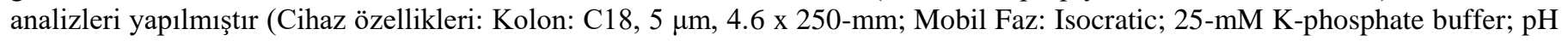
2.4; Akış Hızı: 1.5 mL/min.; Kolon Sıcaklığı: $30^{\circ}$ C; UV Dedektör: Wavelength: 210 nm; Enjeksiyon Hacmi: $20 \mu \mathrm{L}$ ).

Mikrobiyolojik Analizler: Her bir silajda Stanley vd. (1971)' nın bildirdiği yönteme göre sülfit indirgeyen anaeroblar, Harrigan (1998)' in bildirdiği yönteme göre de laktik asit bakteri sayısı, Enterobacteriaceae, Listeria spp., maya ve küf olup olmadığı belirlenmiştir.

Duyusal Analizler: Silajların açılmasıyla birlikte, silajlara ait fiziksel özellikleri (renk, koku ve strüktür) ve kalite puanları, deneyim sahibi 6 panelist tarafından Alman Tarım Örgütü (DLG, 1987) silaj değerlendirme cetvelleri kullanılarak yapılmııstır.

İstatistik Analizleri: Elde edilen sonuçlar, SPSS 16.01 paket programda One-Way Anova prosedürüne göre analiz edilmiş olup, grupların farklı1ıkları için Duncan Çoklu Karşılaştırma Testi uygulanmıştır. Ayrıca silajların mikrobiyolojik analizleri yine SPSS Paket Programı'nda Sıklık prosedürüne göre analiz edilmiştir (SPSS, 2007).

\section{Bulgular ve Tartışma}

Tablo 1'de verilen değerler incelendiğinde, lavantanın (çiçek+sap) yonca silajlarına farklı düzeylerde ilavesiyle kuru madde içeriğinde önemli bir değişiklik görülmemiştir ( $\mathrm{P}>0.05)$. Silolama her ne kadar koşullarda yapılsa da iyi kalitede silaj için gerekli fermentasyon koşulları sağlanamadığında silajlarda bulunması istenmeyen mikroorganizmaların çoğalmasıyla kuru madde kayıpları söz konusu olmaktadır (Bolsen vd., 1996). Sonuç olarak, yonca silajlarına lavanta katkısının siloda istenmeyen unsurların gelişimini durdurarak kuru madde kayıplarını durdurduğu söylenebilir. Ayrıca farklı düzeylerde lavanta içeren yonca silajlarında görülen \% 25.24-26.53 arasında değişen kuru madde oranları literatür bildirişleri ile uyumludur. Yonca silajlarına farklı katkı maddesi ilave eden Pour vd. (2017) ve Koç vd. (2017) benzer sonuçlar elde etmişlerdir. Farklı düzeylerde lavanta ilavesiyle yonca silajlarının ham kül, organik madde ve ADF içeriklerinde önemli bir farklılık saptanmamıştır ( $\mathrm{P}>0.05)$. Yonca silajlarına Çiftçi vd. (2005) elma püresi ve Koç vd. (2017) inokulant ilavesiyle ham kül, ham protein ve ADF içeriklerinin değişmediğini bildirmişlerdir. \% 2 lavanta ilavesiyle yonca silajlarının NDF içeriğinin arttığı görülmüştür ( $\mathrm{P}<0.05)$. Ke vd (2015), yoncaya elma ve üzüm posası ilavesiyle silajların NDF içeriğinin arttığını belirtmişlerdir. Sonuçlar arasındaki bu farklılık yonca silajlarının farklı 
katkı materyalleri ile silolanmasından kaynaklanmış olabilir. Fermentasyon artırıcı olarak silajlarda kullanılan lavantanın özellikle sap kısmının NDF değerinin nispeten yüksek olması, silajlardaki düzeyi arttıkça NDF değerinin artmasına etki etmiş olabilir.

Tablo 1. Lavanta (çiçek+sap) ilave edilen yonca silajlarının kimyasal analizleri

\begin{tabular}{lccccccc}
\hline Parametreler & Kontrol & $\begin{array}{c}\% \text { \% } 0.5 \\
\text { Lavanta }\end{array}$ & $\begin{array}{c}\text { \% } 1.0 \\
\text { Lavanta }\end{array}$ & $\begin{array}{c}\text { \% } 1.5 \\
\text { Lavanta }\end{array}$ & $\begin{array}{c}\text { \% 2.0 } \\
\text { Lavanta }\end{array}$ & $\bar{X}$ & P \\
\hline KM, \% & 25.50 & 25.24 & 25.62 & 25.70 & 26.53 & 25.72 & 0.48 \\
HK, \% & 13.49 & 14.93 & 14.43 & 14.91 & 14.60 & 14.42 & 0.01 \\
OM, \% KM & 10.98 & 9.94 & 11.20 & 10.58 & 11.64 & 10.86 & 0.43 \\
NDF, \% KM & $34.95^{\mathrm{b}}$ & $33.92^{\mathrm{b}}$ & $33.36^{\mathrm{b}}$ & $34.00^{\mathrm{b}}$ & $37.93^{\mathrm{a}}$ & 34.85 & 0.03 \\
ADF, \% KM & 27.27 & 25.38 & 26.22 & 25.72 & 28.65 & 26.71 & 0.18 \\
HP, \% KM & 18.54 & 18.77 & 18.74 & 18.39 & 17.96 & 18.48 & 0.38 \\
\hline
\end{tabular}

a-b Aynı satırda farklı harfleri taşıyan gruplar içerisindeki farklılıklar istatistiki olarak önemlidir $(\mathrm{P}<0.05)$.

KM: Kuru Madde; OM: Organik Madde; HK: Ham Kül; NDF: Nötr Deterjan Fiber; ADF: Asit Deterjan Fiber; HP: Ham Protein

Lavanta (çiçek+sap) ilave edilen yonca silajları fermentasyon özellikler bakımından incelendiğinde ise (Tablo 2), kontrol grubunun $\mathrm{pH}$ değeri, \% 0.5, 1.0 ve \% 1.5 lavanta ilave edilen gruplara nazaran önemli düzeyde düşük olduğu belirlenmiştir $(\mathrm{P}<0.05)$.Lavanta katkılı yonca silajlarının laktik asit içerikleri arasında önemli bir farklılık olmadığı belirlenmiştir ( $\mathrm{P}>0.05)$. Lavanta ilaveli yonca silajlarında asetik asit ve bütirik asit içeriğine rastlanmamıştır. Kontrol grubunda $\% 0.98$ düzeyinde propiyonik asit içeriği saptanmış olup, diğer gruplarda propiyonik asit içeriği tespit edilememiştir. Silajların kalitesini, fermentasyonu esnasında oluşan pH ve organik asitlerin miktarı ve kompozisyonları belirlemektedir. Fermentasyonun erken aşamasında ortam pH'sındaki düşüş hızı iyi bir silaj elde etmek için büyük önem taşımaktadır. Bu bulgular, yonca silajlarına fermentasyon artırıcı olarak Canbolat vd. (2013)'nın gladiçya meyvesi; Ünlü vd. (2015)'nın öğütülmüş dane mısır; Denek vd. (2012)'nın taze ve donmuş fermente sıvı ilavesi ile pH değerinin düştüğü ve laktik asit içeriğinin ise arttığını bildirdikleri bulgularla uyumlu değildir. Bu çalışmalarda yonca silajlarında farklı düzeylerde farklı katkı maddeleri kullanıldığından çalışmaya benzer sonuçlar elde edilemediği ve lavanta sapının pH değerini artırdığı düşünülmektedir. Bütirik asit bakterileri, silajların fermentasyon esnasında asetik asit bakterilerinin en önemli rakibidir. Bunun nedeni, silo yemlerinde bütirik asit üretimiyle önemli miktarda besin madde kaybı meydana gelmektedir. Bu bakteriler, asetik asit bakterilerinin kullandığı karbonhidratları kullanarak ihtiyaçları olan besin maddelerini ya çok azaltırlar ya da tamamen tüketmektedirler. Bu nedenle silajlarda bütirik asit istenmemektedir (Alçiçek\&Özkan, 1997). Yoncaya lavanta ilave edilmesiyle elde edilen silajlardaki yeterli laktik asit içeriği ve istenilen seviyelere yakın olduğu tespit edilen pH değerleri, bütirik asit bakterilerinin çoğalmasını engelleyerek silonun fermentasyonun olumsuz yönde gelişmesini önlemiştir. Filya vd. (2001) ve Tabacco vd. (2006), yonca silajlarına katkı maddesi ilavesiyle bütirik asit içeriğinin olmadığını belirtmişlerdir.

Tablo 2. Lavanta (çiçek+sap) ilave edilen yonca silajlarının fermentasyon özellikleri

\begin{tabular}{lccccccc}
\hline Parametreler & Kontrol & $\begin{array}{c}\% 0.5 \\
\text { Lavanta }\end{array}$ & $\begin{array}{c}\% 1.0 \\
\text { Lavanta }\end{array}$ & $\begin{array}{c}\% 1.5 \\
\text { Lavanta }\end{array}$ & $\begin{array}{c}\% 2.0 \\
\text { Lavanta }\end{array}$ & $\overline{\mathrm{X}}$ & P \\
\hline $\mathrm{pH}$ & $5.09^{\mathrm{b}}$ & $5.51^{\mathrm{a}}$ & $5.41^{\mathrm{a}}$ & $5.52^{\mathrm{a}}$ & $5.20^{\mathrm{ab}}$ & 5.32 & 0.02 \\
$\mathrm{LA}, \%$ & 3.02 & 3.20 & 2.97 & 2.97 & 2.74 & 2.98 & 0.92 \\
$\mathrm{AA}, \%$ & - & - & - & - & - & & \\
$\mathrm{PA}, \%$ & 0.98 & - & - & - & - & & \\
$\mathrm{BA}, \%$ & - & - & - & - & - & &
\end{tabular}

a-b Aynı satırda farklı harfleri taşıyan gruplar içerisindeki farklılıklar istatistiki olarak önemlidir $(\mathrm{P}<0.05)$.

LA: Laktik asit; AA: Asetik asit; PA: Propiyonik asit; BA: Bütirik asit.

Farklı düzeylerde lavanta ilave edilen yonca silajlarının mikrobiyolojik analizlerine ait sonuçlar Tablo 3'de verilmiştir. Bu sonuçlara göre, \% 2.0 lavanta ilave edilen yonca silajlarının laktik asit bakteri sayısı diğer gruplara nazaran önemli düzeyde yüksek bulunmuştur $(\mathrm{P}<0.01)$. Araştırmadaki bütün gruplarda Enterobacteriaceae, Listeria spp., maya ve sülfit indirgeyen anaeroblara rastlanmamıştır. En yüksek küf içeriğine kontrol grubunda rastlanırken, en düşük \% 0.5 lavanta içeren grupta sadece bir örnekte $2.3 \log \mathrm{cfu} / \mathrm{g}$ olduğu belirlenmiştir. Silajlara oksijen girişi olduğunda veya iyi bir silolama yapılamadığı durumlarda özellikle küf ve maya populasyonu olmak üzere istenmeyen mikroorganizmaların silo kabı içerisinde içeriği giderek artmaktadır. Sonuç olarak, silajda büyük oranda ve gözle görülür bir şekilde bozulma meydana gelmektedir. Bu zararlı mikroorganizmalar, silaj bünyesindeki suda çözünebilir karbonhidratlar, organik asitler ve nitrojenli bileşikler gibi eriyebilir komponentleri tüketmek suretiyle kendilerini geliştirmektedirler. Sonuç olarak, silajların içerdiği besin maddeleri oranı azalmaktadır (Filya, 2005). Yoncaya lavanta ilavesiyle silajlarda laktik asit bakteri sayısı artarak istenmeyen mikroorganizmaların gelişimini baskıladığı hatta oluşunu önlediği anlaşılmaktadır. Benzer şekilde, Canbolat vd. (2013), gladiçya meyvesinin yonca silajlarına ilavesiyle laktik asit bakterileri sayısının arttığını ve küflenmenin azaldığını belirtmişlerdir. 
Tablo 3. Lavanta (çiçek+sap) ilave edilen yonca silajlarının mikrobiyolojik özellikleri (log cfu/g)

\begin{tabular}{|c|c|c|c|c|c|}
\hline Parametreler & Kontrol & $\begin{array}{c}\% 0.5 \\
\text { Lavanta }\end{array}$ & $\begin{array}{c}\% 1.0 \\
\text { Lavanta }\end{array}$ & $\begin{array}{c}\% 1.5 \\
\text { Lavanta }\end{array}$ & $\begin{array}{c}\% 2.0 \\
\text { Lavanta }\end{array}$ \\
\hline Laktik Asit Bakterileri* & $4.37 \pm 0.20^{\mathrm{b}}$ & $4.51 \pm 0.17^{\mathrm{b}}$ & $4.13 \pm 0.15^{\mathrm{b}}$ & $4.40 \pm 0.04^{\mathrm{b}}$ & $5.15 \pm 0.09^{\mathrm{a}}$ \\
\hline Enterobacteriaceae & - & - & - & - & - \\
\hline Listeria $\mathrm{spp}$ & - & - & - & - & - \\
\hline Sülfit İndirgeyen Anaeroblar & - & - & - & - & - \\
\hline Maya & - & - & - & - & - \\
\hline Küf & $\begin{array}{c}4.37 \\
\text { (2 örnek } \\
\text { ortalaması) }\end{array}$ & $\begin{array}{c}2.3 \\
\text { (1 örnek) }\end{array}$ & $\begin{array}{c}3.8 \\
\text { (2 örnek } \\
\text { ortalaması) }\end{array}$ & $\begin{array}{c}2.9 \\
\text { (1 örnek) }\end{array}$ & $\begin{array}{c}2.75 \\
\text { (2 örnek } \\
\text { ortalaması) }\end{array}$ \\
\hline
\end{tabular}

${ }^{\text {a-b }}$ Aynı satırda farklı harfleri taşıyan gruplar içerisindeki farklılıklar istatistiki olarak önemlidir $(\mathrm{P}<0.01)$.

Lavanta katkılı yonca silajları görünüşleri bakımından incelendiğinde (Tablo 4), gruplar arasında önemli bir farklılık bulunmamıştır. \% 2 lavanta ilave edilen grubun toplam kalite değeri gruplar arasındaki en yüksek değer olarak 14.12 olarak belirlenmişse de bu değer sayısal düzeyde kalmıştır. Alman Tarım Örgütü (DLG, 1987) tarafından önerilen silaj değerlendirme cetveli kullanılarak yapılan silaj kalite saptamasında, 16-20 puan arası "pekiyi", 10-15 puan arası da "memnuniyet verici" olarak nitelendirilmektedir. Yoncaya farklı düzeylerde lavanta ilavesiyle elde edilen silajların toplam kalite sınıfını bütün gruplarda “Memnuniyet Verici” olarak belirlenmiştir. Ünlü vd. (2015)'nın yoncaya öğütülmüş dane mısır ilavesiyle renk değerlendirmesinde önemli farklılık olmadığının ancak strüktür ve koku kriterlerinin iyileştiği sonucuna varmışlardır $(\mathrm{P}<0.01)$. Benzer bir çalışmada, Arslan Duru ve Aksu Elmalı (2016), yoncaya mısır kırması, buğday kırması, melas ve formik asit ilavesiyle silajların kokularında önemli bir değişiklik olmadığı $(\mathrm{P}>0.05)$ ancak strüktür ve rengin özellikle de melas içeren grupta iyileştiğini bildirmişlerdir.

Tablo 4. Lavanta (çiçek+sap) ilave edilen yonca silajlarının duyusal analizleri

\begin{tabular}{lccccccc}
\hline Parametreler & \multirow{2}{*}{ Kontrol } & $\begin{array}{c}\text { \% } 0.5 \\
\text { Lavanta }\end{array}$ & $\begin{array}{c}\text { \% } 1.0 \\
\text { Lavanta }\end{array}$ & $\begin{array}{c}\text { \% } 1.5 \\
\text { Lavanta }\end{array}$ & $\begin{array}{c}\text { \% 2.0 } \\
\text { Lavanta }\end{array}$ & $\bar{X}$ & P \\
\hline Koku & 8.11 & 8.33 & 9.00 & 7.78 & 9.78 & 8.60 & 0.61 \\
Strüktür & 3.11 & 2.83 & 3.06 & 3.06 & 2.78 & 2.97 & 0.84 \\
Renk & 1.56 & 1.50 & 1.56 & 1.56 & 1.56 & 1.54 & 0.99 \\
\hline Toplam & $\mathbf{1 2 . 7 8}$ & $\mathbf{1 2 . 6 6}$ & $\mathbf{1 3 . 6 2}$ & $\mathbf{1 2 . 4 0}$ & $\mathbf{1 4 . 1 2}$ & $\mathbf{1 3 . 1 1}$ \\
\hline Kalite Sinıfi & M.V.* & M.V. & M.V. & M.V. & M.V. & & \\
\hline
\end{tabular}

*M.V.: Memnuniyet Verici

\section{Sonuç}

Çalışma sonunda elde edilen veriler neticesinde, \% 2 lavanta içeren grubun NDF içeriği yükselmiş ve kontrol grubunun pH değeri düşük bulunmuştur. Ancak silajlarda bütirik asit içeriğine rastlanmamış ve laktik asit içeriği istenen seviyelerde olduğu görülmüştür. Duyusal analiz değerleri dikkate alındığında ise, \% 2 lavanta içeren grubun en yüksek değerde olduğu anlaşılmışsa da sayısal düzeyde kalmıştır. Ayrıca lavanta ilavesi ile silajlarda laktik asit bakteri sayısı artmış ve küf miktarında azalma görülmüştür. Silajlarda koruyucu olarak kullanılabilecek potansiyele sahip lavantanın ya daha yüksek miktarlarda ya da sap kısmının ayrılarak silajlara ilave edilmesi konusunda çalışmalar yapılması gerekli olduğu sonucuna varılmıştır.

\section{Teşekkür}

Bu çalışma, "II. International Scientific and Vocational Studies Congress (BILMES 2018)” kapsamında sunulmuştur.

\section{Referanslar}

Alçiçek, A. \& Özkan, K. (1997). Silo yemlerinde fiziksel ve kimyasal yöntemlerle silaj kalitesinin saptanması. Türkiye I. Silaj Kong. Bildirileri. 16-19 Eylül, Bursa, 241-246.

Ankom, (1998). Procedures for fibre and in vitro analysis. Asseda. http://www.ankom.com.

AOAC (1999). Official Methods of Analysis. Association of Official Analytical Chemists, 16th Ed., Arlington VA.

Arabacı, O. \& Bayram, E. (2005). Aydın Ekolojik Koşullarında Lavanta (Lavandula Angustifolia Mill.)’nın bazı Agronomik ve Kalite Özellikleri Üzerine Bitki Sıklığı ve Azotlu Gübrenin Etkisi. ADÜ Ziraat Fakültesi Dergisi, 2(2): 13-19. 
Arslan Duru, A. \& Aksu Elmalı D. (2016). Farklı Katkı Maddelerinin Yonca Silajlarında Bazı Kalite Özellikleri Üzerine Etkisi. 1st of International INES Academic Researches Congress (INES 2016), Antalya, Turkey.

Aslancan, H. \& Sarıbaş, R. (2011). Lavanta Yetiştiriciliği. Meyvecilik Araştırma Enstitüsü Müdürlüğü. Yayın No.41.

Atalay, A.T. (2008). Konya ekolojik şartlarında yetiştirilen lavanta (lavandula angustifolia mill.)'Da farklı dozlarda Uygulanan organik ve inorganik azotlu gübrelerin verim ve kalite özellikleri üzerine etkileri. Selçuk Üniversitesi Fen Bilimleri Enstitüsü Tarla Bitkileri Anabilim Dalı. Yüsek Lisans Tezi, 46 s.

Bolsen, K.K., Ashbell, G. \& Weinberg, Z.G. (1996). Silage fermentation and silage additives. Asian Austral J Anim Sci, 9 (5): 483-493, 1996. doi:5713/ajas.1996.483

Canbolat Ö., Kalkan H. \& Filya İ. (2013). Yonca Silajlarında Katkı Maddesi Olarak Gladiçya Meyvelerinin (Gleditsia Triacanthos) Kullanılma Olanakları. Kafkas Üniv Vet Fak Derg, 19 (2): 291-297. doi: 10.9775/kvfd.2012.7710

Canbolat Ö., Kalkan H., Karaman Ş. \& Filya İ. (2010). Üzüm Posasının Yonca Silajlarında Karbonhidrat Kaynağı Olarak Kullanılma Olanakları. Kafkas Univ Vet Fak Derg, 16 (2), 269-276. doi:10.9775/kvfd.2009.679

Çiftçi M., Çerçi İ.H., Dalkılıç B., Güler T. \& Ertaş O.N. (2005). Elmanın Karbonhidrat Kaynağı Olarak Yonca Silajına Katılma Olanağının Araştırılması. YYÜ Vet Fak Derg, 16 (2), 93-98. ISSN: 1308-3651

Denek, N., Can A., Avc1, M \& Aksu, T. (2012). The effect of fresh and frozen pre-fermented juice on the fermentation quality of alfalfa silage. Kafkas Unv. Vet. Fak. Derg.,18(5): 785-790. doi: 10.9775/kvfd.2012.6396

Djabri, B., Rouabhi, R., Arhab, R., Attar, F. \& Bousseboua, H. (2016). Antimethanogenic activity of essential oils extracted from Rosmarinus officinalis and Lavandula officinalis. BioTechnology An Indian Journal, 12(2): 107-112. ISSN : 0974 - 7435

DLG (1987). Energie- und Na“hrstoffbedarf landwirtschaftlicher Nutztiere. 4. Schweine. DLG-Verlag GmbH, Frankfurt, Germany.

Ergün A., Tuncer Ş. D., Çolpan İ., Yalçın S., Yıldız G., Küçükersan M. K., Küçükersan S., Şehu A. \& Saçaklı P. (2013). Yemler Yem Hijyeni ve Teknolojisi. Pozitif matbaacılık, Ankara, Türkiye. pp. 61-97.

Filya, İ., Ashbell, G., Weinberg, Z.G. \& Hen, Y. (2001). Hücre duvarını parçalayıcı enzimlerin yonca silajlarının fermantasyon özellikleri, hücre duvarı kapsamı. ve aerobik stabiliteleri üzerine etkileri. Ankara Üniv Zir Fak Tarım Bilim Derg,7 (3): 81-87, 2001. doi: 10.1501/Tarımbil_0000000652

Filya, İ. (2005). Silaj Yapımı Teknolojisi ve Kullanımı. Sütaş Süt Hayvancılığı Eğitim Merkezi Yayınları. Hayvancılık Serisi: 2. Yetiştirici El Kitabı.

Guenther, E. (1952). The Essential Oils. Van Nostrand, New York, USA, p. 453.

Harrigan, W. F., (1998), Laboratory methods in food microbiology 3nd ed., Academic Pres, London, UK.,

Hashemzadeh-Cigari, F., Khorvash, M., Ghorbani, G.R., Ghasemi, E., Taghizadeh, A., Kargar, S. \& Yang, W.Z. (2014) Interactive effects of molasses by homofermentative and heterofermentative inoculants on fermentation quality, nitrogen fractionation, nutritive value and aerobic stability of wilted alfalfa (Medicago sativa L) silage. J Anim Physiol Anim Nutr 98, 290-299. doi: $10.1111 /$ jpn. 12079

Ke, W.C., Yang, F.Y., Undersander, D. J. \& Guo, X.S. 2015. Fermentation characteristics, aerobic stability, proteolysis and lipid composition of alfalfa silage ensiled with apple or grape pomace. Animal Feed Science and Technology 202 (2015) 12-19. doi: 10.1016/j.anifeedsci.2015.01.009

Kesici Güler, H., Dönmez, İ.E. \& Alay Aksoy, S. (2015). Tıbbi ve Aromatik Bitkilerin Antibakteriyel Aktivitesi ve Tekstil Sektöründe Kullanımı. SDU Journal of Science. 10 (2): 27-34.

Koç, F., Aksoy, S.O., Okur, A.A., Celikyurt, G., Korucu, D. \& Ozduven, M.L. 2017. Effect of pre-fermented juice, Lactobacillus plantarum and Lactobacillus buchneri on the fermentation characteristics and aerobic stability of high dry matter alfalfa bale silage. The Journal of Animal \& Plant Sciences, 27(6): 1766-1773. ISSN: 1018-7081

Lee, K.C. (1988). The effect of ensiling on the quality of forage crops. Herbage abstracts/National Library of Australia. 58.6.1481.

Orbay, A.E. (2014). Konya çevresinde yetişen içilebilir bazı tıbbi bitkilerin yă̆ asit kompozisyonlarının belirlenmesi ve karşılaştırılması. Selçuk Üniversitesi Fen Bilimleri Enstitüsü Kimya Anabilim Dalı. Yüksek Lisans Tezi, 66 s. 
Polan, C.E.,Stive, D.E. \& Garrett, J.L. (1998). Protein preservation and ruminal degradation of ensiled forage treated with heat, formic acid, ammonia, or microbial inoculant, Journal of Dairy Science, 81, 765-776. doi: 10.3168/jds.S0022-0302(98)75633-4

Pour, H.A., Naserian, A.A., Vakili, A.R., Tahmasbi, A.M. (2017). Effect of Essential Plant Oil Used as an Additive to Alter Silage Fermentation in Ruminant by In Vitro. Biosciences Biotechnology Research Asia. 14(1), 145-152. doi: http://dx.doi.org/10.13005/bbra/2429

SPSS (2007). SPSS for Windows Release 16.01. SPSS Incorporation. 2007.

Stanley, E. R., Bradley, T. R., \& Sumner, M. A. (1971). Properties of the mouse embryo conditioned medium factor(s) stimulationg colony formation by mouse bone marrow cells grown in vitro. J. Cell. Physiol. 78, 301-317. doi: 10.1002/jcp.1040780219

Şakalar, B. \& Kamalak A. (2016). Melaslı kuru şeker pancarı posasının yonca bitkisinin silolanmasında kullanılması. Anadolu Tarım Bilim. Derg. 31: 157-164. doi: 10.7161/anajas.2016.31.1.157-164

Ünlü, H.B., Ayyılmaz, T. \& Kılıç, A. (2015). Farklı düzeylerde öğütülmüş dane mısır ilavesinin yonca silajının yem değeri üzerine etkisi. Ege Üniversitesi Ziraat Fakültesi Dergisi, 52 (3): 335-341. doi: 10.20289/euzfd.07936

Van Soest P. J., Robertson J. D. \& Lewis B. A. (1991). Methods for Dietary Fibre, Neutral Detergent Fibre and Non-Starch Polysaccharides in Relation to Animal Nutrition, Journal of Dairy Science, 74, 3583-3597. doi: 10.3168/jds.S00220302(91)78551-2. 